\title{
SCIENCE IN SECONDARY SCHOOLS
}

\author{
Florence A. Gates, Toledo, Ohio
}

After reading a series of articles on this subject in numerous educational magazines and books, published during the last five years, we started to list the adverse and constructive criticisms, as well as favorable characteristics of present work. Our fingers cramped as we listed the adverse criticisms, the suggestions for betterment were few and far between, and the strong points of our present work were almost conspicuous by their absence. We are wondering if some good Samaritan will not come to our rescue and remind us that life is worth living.

Science enrollment in secondary schools has greatly decreased during the past decade, with a decided decline in physics, chemistry barely able to hold its own, an upward stride in biology, not due to attractions offered by the course, but a uniting of the old semester courses of botany and zoology; and last, but not least, a rise in general science, which replaces the almost extinct courses of physiology, physical geography, hygiene and agriculture.

Furthermore, we teachers have no appreciation of the objectives of science or principles of subject matter or its organization. We lack breadth of education, or, we are not specialists; we make physics and chemistry too difficult; we waste too much time in demonstration and lecture, or we allow too much time for individual laboratory work, and thus waste fifty percent of the time and nearly double the expense. We attempt to educate for college with the result that "the average college preparation presents to the university, the most narrow and unevenly trained material that can be imagined." We teachers have failed to note the popular demand for science reading and have failed to develop a corresponding interest. One writer states that we have scarcely begun to teach possibilities. Our pupils are simply "patient sufferers with poor teachers," who are taught daily, material that is seldom or never met with in business. Too much emphasis has been placed on methods of teaching, while the organization of the curriculum and provision for suitable teachers has been neglected. Superintendents and principals discourage pupils from entering these courses, on account of cost.

We have found a few defenders in our search for rebuttals. Dr. Downing (1) of Chicago, in his replies to Dr. Millikan of Los Angeles (2), tells us that men who are supposed to be saturated with the scientific attitude of mind, fail to see that the problems of teaching must be attacked in the same way as problems of physical and biological sciences. Curtis (3), of Michigan, has listed a great series of experiments along the lines of secondary science, which have led to greater efficiency in teaching methods, and conservation of time, money, and energy. Harris (4), of Minnesota, has been a source of great inspiration in showing the value of biology in our secondary schools.

In the past ten years, we have seen the practical annihilation of semester courses in science, the old-fashioned book with its uniform lists of questions and answers, experiments and drawings, the courses so closely modeled after ones in colleges that our graduates boasted that they were excused from some college work, the herbariums of pressed flowers, the over emphasis of mathematics in the

Proc. Ind. Acad. Sci. 40: 51-56. (1930) 1931. 
physics work, and of morphology and taxonomy in biology, together with a lessening in the use of the microscope in the first two years.

With these eliminated from our work, someone may wonder just what we are trying to do. We cannot say that all of the following are being carried out in all schools of the country, but there are trends in the various directions, that are outstanding.

First, there has been a radical change in the curricula of secondary schools, in that courses are planned that will fit the individual for life and special courses for those who prepare especially for college entrance. General science, fighting for its life for a number of years, has now been generally recognized as a ninth year science and to be a requirement in all courses, replacing, as we have mentioned before, the old semester ones. In New England, both general science and biology are taught as ninth year sciences, while in the state of New York, biology is still required in this year, with opposition to it on the increase. In the Central states, there is quite a variation in the first year requirement, with the swing toward general science.

Biology is now generally recognized as a tenth year subject, but it is usually classed as an elective. There was a trend, a few years ago, towards placing it in the required class, but because of it laboratory periods interfering with the complex curricula of our larger high schools, it is required in but few courses. From a recent survey of our own biology courses, we found that fifty percent elect it because of interest in plants and animals, twenty percent as a preparation for life work, sixteen percent because it is required and the remaining fourteen percent as a substitute for a more difficult subject.

Physics is settling in the third, with chemistry in the fourth. With the fewer pupils enrolling in the college preparatory courses, we are seeing a decline in physics enrollment, the Bureau of Education report for 1928 showing a fall of eight percent. While chemistry is fairly stationary, some believing that its enrollment is maintained by interest emanating from scientific societies, we find that local conditions vary. In the secondary school, with which we are most familiar, we have a present enrollment of 99 in physies and over 300 in chemistry, including three night classes.

However in our larger high schools, both academic and technical, we are offering numerous specialized courses, either one or two semesters, either for college entrance or preparation for various professions or occupations, most of these courses coming in the third or fourth year. In one of our secondary schools, where a number of graduates enter eastern colleges, and where our freshmen are grouped according to age and mentality, we are giving the four so-called "master groups" a year's work in physical geography for college entrance, thus catering to the eastern group, who do not as yet, recognize general science.

Courses in human biology, bacteriology, specialized botany or zoology are being offered in the third and fourth year. Our chemistry and physies classes are now being divided into general and academic, those in the general classes in physies having less mathematies, and a closer application to everyday life. Our academic classes in chemistry are receiving more theory and do more individual experiments, while the general students, those of average ability or less, are having more work of the lecture-demonstration type.

Our biology pupils no longer have one microscope for one or even two pupils in a class, but a few microscopes in each class. Microscopic work to a great extent, has been eliminated. We feel that the movie picture machine, the balopticon and 
simple charts, can create an understanding superior to that of the microscope for the average pupil, though we realize that no demonstration can replace it for some topies, or that we would abandon its use in case of superior pupils, who readily interpret what they see. There is a tendency, too, for a reduction in the time and energy given to dissection, much of this work now being done by the teacher or specially interested pupils, who then demonstrate to the class.

The content of our courses is becoming more or less woven about large objectives, or which the outstanding seems to be those, which deal with the adjustment of the individual to his environment. One author (5), states in writing of biology, but the same could be applied to all sciences, that the highest objective is a scientific attitude of mind, which will enable him to meet all sorts of situations with sanity and confidence, which is another way of expressing the same thought. The findings of science that approach in the lives of our pupils, the ability to interpret natural phenomena, the understanding and ability to use methods of study, all of these are objectives upon which the modern courses are based.

We are weaving our courses around life interests. We have seen a good working course in chemistry, worked out on the unit plan, for use in a high school in Hilo, Hawaii, with the units bearing titles as The Chemistry of Fire, The Chemistry of Warfare, Chemistry and its Relation to Agriculture. Most modern chemistry courses stress its application to industry. Biology courses are beginning to follow similar lines, and instead of the old topics of Insects, Fishes, Thallophytes, etc., we read Biology and Its Relation to Health, Biology and the Household, Biology in the Field, Garden, and Stream. Live headings of this nature cannot fail to attract students and sustain interest. The topics in most general science courses have the vital element in them. Attempts have been made to vitalize physics, but the tendency seems to hold rather firmly to the old traditions.

"Our newer textbooks are lending themselves more to human interest," the statement coming from a college professor. One authority, who criticized our present work adversely, claims that one textbook is as good as another. We have wondered just how many he had examined, and how many of these he had tried out with pupils of high school age. However, our modern teachers agree with another authority, that whenever we teach from logical texts, we wrongly attempt to induce pupils to accept topics as their projects. The tendency these days is to treat the so-called physics, chemistry or biology textbook as a reference text, choosing one that is more or less general, and supplementing this with much reading in other texts, other books, magazines and papers. The amount of reference work, however, again varies with the mentality of the pupil.

The notebook is undergoing keen revision. Some of us can remember the days when the notebook in secondary science was considered as a showpiece for visitor's, or for the annual school exhibition or the county fair, when the teacher's reappointment hung on whether or not his or her notebooks received prizes. Uniformity of notebooks was held before the pupils and woe to the pupil, who attempted anything original. We have seen biology units, cleverly illustrated with cartoons, done by a boy, who professed a dislike for study, but he managed to maintain a high rank in this subject. Elaborate microscopic drawings, of ten surreptitiously copied from books filling page after page, drawings of simple things that wasted time of pupils, who learned nothing new by this work, detailed shaded and colored drawings showing structure, experiments which the teachers practically dictated, are done away with by progressive teachers. 
Pupils are taught that the purpose of a drawing is to fix another impression in their minds. Detailed representative drawings, exact representations, are being replaced by analytical drawings, which are combinations of main points, diagrams and parts not seen by the pupil. If a pupil asks us these days "Do you care if I represent this by a circle?" we are delighted, because we know that his note book is no longer a showpiece, with answers to questions some one worked out, but pages that show original thought. The old notebook had drawings neatly placed on separate sheets, in many cases far from the notes referring to them, but the modern notebook has drawings and notes on the same page, notes not in long essay form, but organized by topies and closely related to the drawings. The number of drawings required is not the same for all pupils, this depending upon the mentality of the pupil, his interests and his ambitions. If we have been studying bread mold, following which a pupil brings in mush covered with Monilia, the time for that pupil to study Monilia is then, and his interest is increased and his ambitions quickened, if he can add a drawing of Monilia to his notebook.

Teachers in science need to teach pupils how to study. Newer laboratory manuals are being published, in which completion paragraphs are to be filled in. Training in making charts is gained after a few have been completed. The outline form of writing notes adds to the thought process. No two notebooks need be alike and a repeated use of the above methods leads to the eradication of copying notes from texts, which we hesitate to say, is still being practiced.

We still have the teachers who make out their science tests the evening before, or a few minutes before school, and we have heard of teachers, who rave about the poor grades of their pupils, who at the same time, boast that they never make out the questions until they go to the board. However, these are few in number, and we rejoice in the number who write down questions, as the work suggest them, and gradually work out thought-provoking objective tests. We have seen a science test notebook made by one teacher, with objective tests of the bestanswer, multiple choice, modified true-false, completion and association types filed according to topic and type, the questions gained from experience and correspondence with other schools, and gleaned from educational periodicals and books. All of these take more thought on part of both teacher and pupil, than the hoary one of "Give three characteristics of ............" to be completed by "levers, halogens, blue-green algae" or the "human heart," depending on the course and topic. With the increase in the number of schools, using the unit or project plan, we find a decrease in the number of pupils, who cram for a test the evening before. As one pupil naively stated it, "Gee, when you work out the unit yourself, you always pass the test."

We have shown you some of the things that we are attempting, not forgetting that some educational authorities give as an efficiency test, a rating of forty percent for the pupil, thirty percent for the teacher, ten percent for the equipment, and twenty percent for the plan. Teachers who have had years in science realize the problems of teaching today are far more complicated than those of years ago. School attendance is now compulsory in some states up to eighteen years, with the privilege of continuation part time work after sixteen. These pupils enter our high schools, our own city showing an increase of 300 percent during the past decade. The mentality of many is far below normal, and work has to be devised to fit this mentality. The problem of the boy, and in rare cases, the girl, who is remaining in school to wait for the birthday, is a serious one. Can you imagine such a one entering a physics class? 
The more diversified curriculum has drawn students from our science classes into courses with more interesting titles. The rise of the commercial courses to as great as thirty percent in an average city high school, is draining our resources. In former years, weaker pupils were led blindly out of academic courses into commercial ones, but a fact recently noted, is that these latter courses are drawing more and more from our superior pupils. We do not know whether or not this is general but in our own high school this year, the grouped freshmen rate higher in the commercial groups than in the others.

Classes in science are larger and the number of classes per teacher shows an increase in the cities. Just a few years ago, our city science classes were seven periods each per week and three classes to a teacher. Today the classes are the same size or larger, and we find our general science teachers running five classes per day and the other classes increased to four per teacher. Detroit recently opened two new secondary schools by drawing all their teachers from the other schools, thereby increasing the teaching load, and Toledo is forging to the front in that respect.

For years, elementary teachers have had their work carefully supervised, while the secondary schools were neglected, but in recent years has come the high school supervisor, whose duties are varied, but whose work includes the curriculum, inspection of finances and equipment, and visitations to classrooms. Thus far, our experience has been that such an individual can be considered a source of inspiration and a constructive critic.

As to equipment, most of us have all we need, but we do need to know how to make better use of it. Laboratory supply houses are equipped with intelligent salesmen, and helps of various kinds are furnished free of charge. The budget plan of ordering supplies has proved invaluable to both teacher and board of education. School libraries are no longer shelves filled with English and history books, but a section has been set apart for science.

Perhaps we have deserved all the adverse criticisms mentioned at the beginning of this paper. If, however, we bear in mind that we are not only training faculties of our pupils, but we are aiding in developing the finest and most effective types of citizenship, if we can constantly balance the energy given to pupils and subject matter, if we can teach our pupils to think and to carry over into life the science work they have studied with us, then we believe you will agree with us that science in secondary schools is contributing its share to the educational progress of today.

\section{BIBLIOGRAPHY}

1. Downing, E. R., Problems of Science Teaching in Secondary Schools. School and Society, January 16, 1926.

2. Millikan, R. A., Problems of Science Teaching in Secondary Schools. School and Society, November 21, 1925.

3. Curtis, F. D., Investigations in the Teaching of Science. 1926.

4. Harris, J. A., Real value of Biology in Secondary Education. School and Society, September 4, 1926.

5. Walter, H. E., Teaching Biology in Secondary Schools. School and Society, January, 1925.

6. Powers, S. R., Educational Values of Seience Teaching. Teachers' College Record, October, 1930. 
7. Hunter, G. W., Place of Science in Secondary Schools. School Review, May-June, 1925.

8. Downing, E. R., Objectives of Science in Secondary Schools. School Review, November, 1925.

9. Woodhull, J. W., Teaching of Science. 1918.

10. Smith, V. C., Science Methods and Superstitions. School and Society, January 11, 1930.

11. Monahan, A. G., Science and Its Recognition in the High School Curriculum. School Science and Mathematics, November, 1930.

12. Brownell, H., Wade, F. B., The Teaching of Science and the Science Teacher. 1925. 